\title{
The Effect of US Monetary Policy on the Credit Growth of Emerging Market Economies
}

\author{
Selma ÖNER iD a Cansu ŞARKAYA İÇELLİOĞLU iD b \\ a İstanbul University Cerrahpaşa, Social Science Vocational School, İstanbul, Turkey. ssimen@istanbul.edu.tr \\ b İstanbul University Cerrahpaşa, Social Science Vocational School, İstanbul, Turkey. cansusa@istanbul.edu.tr
}

\begin{tabular}{|c|c|}
\hline ARTICLE INFO & ABSTRACT \\
\hline \multirow{3}{*}{$\begin{array}{l}\text { Keywords: } \\
\text { FED Policy Rates } \\
\text { Emerging Market Economies }\end{array}$} & Monetary \\
\hline & economies through monetary transmission mechanisms. The purpose of this study is to examine the \\
\hline & ect of US monetary policy on the credit growth of emerging market economies. \\
\hline Credit Growth & Methodology - For this purpose, the effects of FED policy rates on the private non-financial credit \\
\hline creait Growtin & to GDP ratios of selected emerging market economies are analysed by panel data. The study \\
\hline Financial Integration & comprises quarterly data over the period of 1990-2018. Austria, Brazil, China, Greece, India, Poland, \\
\hline & Portugal, Russia, and Turkey are determined as representatives of emerging market economies. The \\
\hline Received 8 Augu & Seemingly Unrelated Regression (SUR) is used for model estimation \\
\hline Revised 29 November 2019 & Findings - According to the results, while FED reduces policy rates, credit markets of developing \\
\hline Accepted 5 February 2020 & $\begin{array}{l}\text { countries grow. However, slope and intercept parameters of the regression model are not identical } \\
\text { for all countries. In other words, the sensitivity of national credit markets to FED policy rates varies }\end{array}$ \\
\hline Article Classification: & under the influences of economic, legal and political environments of the countries. \\
\hline Research Article & $\begin{array}{l}\text { Discussion - When the results are evaluated comparatively on the country basis, it is seen that the } \\
\text { credit markets of European emerging economies show the strongest reaction to the changes in US } \\
\text { monetary policy while the credit markets of Turkey and Brazil show the weakest. }\end{array}$ \\
\hline
\end{tabular}

\section{INTRODUCTION}

Studies on the issue of global financial cycle and country experiences indicate that global financial markets and the world economy have become more integrated since 1980s and thereby, spill-overs among countries have also become important. Consequently, policymakers in each country have to consider economic developments in the rest of the world, especially in the advanced economies, when making their decisions. As experienced once again after the 2008 global crisis, US monetary policy implementations constitute the most important part of these developments.

In order to cushion the blow of the 2008 crisis, the Federal Reserve (FED) initiated a bond purchase program under the name of "Quantitative Easing" in November 2008 and rapidly reduced policy rates near to zero. This policy implementation named as "unconventional monetary policy" and continued until October 2014 under three separate Quantitative Easing programs (the Central Bank of the Republic of Turkey [CBRT], 2014: 3). Towards the end of this period, investors perceived the May and June 2013 Federal Open Market Committee (FOMC) announcements as the beginning of the end of unconventional monetary policy, and thereby, U.S. Treasury yields rose significantly after a long break. Sovereign bond yields in emerging markets also rose over this period, and simultaneously, the currencies of most emerging market economies depreciated substantially against the U.S. dollar and stock prices fell. The study of Bowman et al. (2014) reveals that U.S. monetary policy shocks that lower U.S. sovereign yields also lower sovereign yields in most emerging markets. Besides, several country-specific variables, including interest rates, credit default swap (CDS) spreads, inflation rates, currentaccount deficits and more-vulnerable banking systems, drive the vulnerability of these emerging market economies to changes in U.S. monetary policy.

\section{Suggested Citation}

Öner, S., İçellioğlu, C. (2020). The Effect of US Monetary Policy on the Credit Growth of Emerging Market Economies, Journal of Business Research-Turk, 12 (1), 18-27. 


\section{S. Öner - C. İçellioğlu 12/1 (2020) 18-27}

Takáts and Vela (2014) also examine the channels through which monetary policy in advanced economies affects financial conditions in emerging market economies and reveal that; (i) emerging market economy policy rates appear to be conducted by monetary policies of advanced economies which are proxied by the US monetary policy, (ii) emerging market economy long-term interest rates are also affected by the US long-term interest rates importantly, (iii) after the 2008 global crisis, a stronger co-movement of long-term interest rates is observed, and (iv) international reserves and portfolio flows to emerging market economies are significantly affected by factors related to changes in US long-term interest rates.

The size of cross-border capital flows, including volatile portfolio flows, has increased importantly along with the integration of global financial markets. Especially the period of Quantitative Easing in advanced economies caused strong capital flows towards emerging market economies and most of the emerging market countries have used different types of macro-prudential policies to restrain the adverse effects of these volatile shortterm capital flows. Turkey, as one of these countries, has designed and started to use several new tools, such as the interest rate corridor and the Reserve Option Mechanism, in order to decrease the global risk perception sensitivity of portfolio flows in Turkey. Furthermore, the exchange rate and credit growth were exposed to the adverse effects of these strong portfolio inflows and short-term capital. The Turkish Lira appreciated rapidly during this portfolio inflow period, and credit growth in Turkey reached around $35 \%$. Since both of these facts were seen as potential indicators of a financial crisis, the CBRT has used new macro-prudential policies (Fendoğlu et al., 2014).

From this point of view, the direction and strength of the relationship between FED policy rates and credit growth of emerging market economies will be investigated in this study. Austria, Brazil, China, Greece, India, Poland, Portugal, Russia and Turkey have been determined as representatives of emerging market economies, and the effect of FED policy rates on their private non-financial credit to Gross Domestic Product (GDP) ratios is analysed for the 1990-2018 period. The Seemingly Unrelated Regression (SUR), which is one of the heterogeneous panel data methods, is used in the model estimation and analysis results are evaluated comparatively on the country basis. These results indicate that credit markets of developing countries have grown considerably except for the 2008 global crisis period. Total private non-financial credit to GDP ratio has been reached approximately $140 \%$ in Austria, $70 \%$ in Brazil, $200 \%$ in China, $110 \%$ in Greece, $55 \%$ in India, $80 \%$ in Poland, $170 \%$ in Portugal, $65 \%$ in Russia and $85 \%$ in Turkey by the year 2018 (Graph 1).

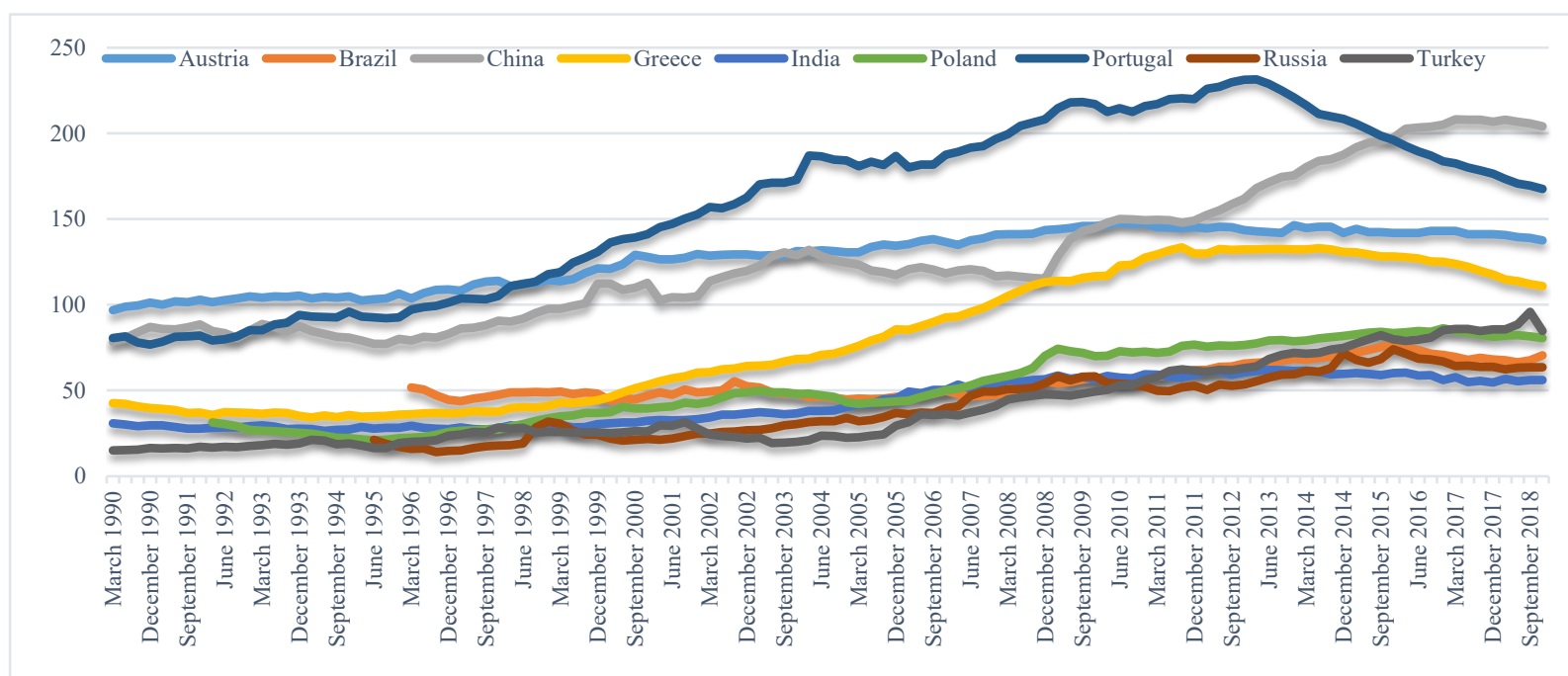

Graph 1. Total Credit to the Non-Financial Sector/GDP Ratios of Emerging Market Economies

Source: Bank for International Settlements, Statistics, [online] https://www.bis.org/, Accessed on June 2019. 


\section{S. Öner - C. İçellioğlu 12/1 (2020) 18-27}

\section{LITERATURE SURVEY}

Since globalization makes financial conditions in emerging market economies closely linked to the monetary policy implications of advanced economies, the number of academic studies in this field has increased rapidly. Most of these studies are examining the mechanisms that link global long-term interest rates to several macrofinancial indicators such as cross-border capital flows, monetary policy, real exchange rates, credit growth, bank leverage and domestic bank lending in the emerging markets.

In one of these studies, Adrian and Shin (2009) state that 2008 global crisis has redirected attention to the monetary transmission mechanisms and tools of monetary policy other than the overnight interest rate. According to their findings, the credit channel of monetary transmission mechanism has been one of the most studied channels. Borio and Zhu (2008) have also suggested a new transmission mechanism, namely risk-taking channel of monetary policy, to define a wide set of effects that result from the expansive behaviour of financial intermediaries and the feedback effects that stem from the credit expansion. According to them, the feedbacks between both perceptions of value and risk, and financing constraints and liquidity has become more prominent.

Aftermath of the global crisis, in order to lessen the burden on the balance sheets of financial intermediaries, the Federal Reserve has put into action several lender-of-last resort programs. The need for the balance-sheet expansion of the Federal Reserve in the post-crisis period indicated that the downfall of the financial sector balance-sheet capacity can have strong adverse effects on the overall capital market conditions and also on the real economy. The mechanism that has increased fluctuations in capital market conditions is the fluctuations in leverage and the related changes in haircuts which is applied by financial intermediaries to the collateral against which they lend in collateralized credit markets. Therefore, an easier US monetary policy that reduces capital and collateral constraints of banks in emerging markets increases the potential to set off credit booms (Adrian and Shin, 2009).

Lane and McQuade (2013) indicate that the balance sheet problems related with rapid credit growth in some countries during the pre-crisis period and excessive external imbalances have been two key factors that contribute to the 2008 global crisis. According to them, if there is a significant relationship between these two variables, international capital flows should be an important issue in the process of understanding the dynamics of domestic credit growth and related risk factors. From this point of view, they examine the inter-relations between domestic credit growth and international capital flows for a sample of European countries including the EU27, plus Norway, Switzerland and Iceland over the period of 1993-2008. Their study also conducts an additional analysis on annual data for an extended sample of 54 countries over the period of 1994-2008. According to the analysis results, international capital flows have strong effects on the national credit growth rates, and therefore, these two variables should be evaluated in an integrated framework.

Bruno and Shin (2013) study on a model of the risk-taking channel of monetary policy transmission. The starting point of their study is the empirical evidence on the determinants of financial crises obtained by Gourinchas and Obstfeld (2011) using data for 1973-2010 period for both advanced and emerging economies. They find that the two most robust predictors of crises in general, for both emerging and advanced economies, are domestic credit growth, in other words increase in leverage, and real currency appreciation. Because credit booms also contribute real currency appreciation, which thereafter leads to low international competitiveness, countries that experience both of these simultaneously are most likely to be vulnerable to financial crisis. They also state the level of foreign exchange reserves of the country as a third robust predictor of crises but for only emerging markets.

From this point of view, Bruno and Shin (2013) imply that although expansionary monetary policies of advanced economies are the driving forces of international capital flows, and so excessive credit growth in the recipient economies, the exact economic mechanism behind such a transmission is more difficult to determine. They point out bank leverage as the linchpin in the risk-taking channel of monetary policy transmission that transfers lower risk measures into greater risk-taking, and then to other real and financial variables, particularly capital flows and exchange rates. They also state that a contractionary shock to US monetary policy 


\section{S. Öner - C. İçellioğlu 12/1 (2020) 18-27}

causes a decrease in the international capital flows in the banking sector, which in turn affects the credit growth indirectly.

Bruno and Shin (2014) also study on the explanation of the link between banking sector capital flows and US monetary policy. Their panel study comprises data from 46 developed and developing economies for the sample period of 1996Q1-2011Q 4 , and investigates the monetary policy spill-overs, particularly the impact of lower US dollar borrowing rates on global financial conditions. They use the risk-taking channel of monetary transmission to explain the link between local currency appreciation and loosening of financial conditions through developing a leverage in the banking sector. Accordingly, when the local currency appreciates as a result of the unconventional monetary policy of US, local borrowers' balance sheets become stronger, and so the credit risk decreases and bank lending capacity expands. In other words, currency appreciation causes greater risktaking by banks, which results in credit booms and increased vulnerability to financial crisis.

Miyajima et al. (2014) examine the role of long-term interest rates in the international monetary transmission mechanisms and related challenges in policy implementations as a result of the unconventional monetary policy of US. For this purpose, a panel VAR model is used to analyse the impact of a very low US term premium on relatively small open Asian economies. The model is applied to monthly data for two samples spanning January 2003-December 2007 and June 2009-December 2013 and focus on five Asian economies, Indonesia, Korea, Malaysia, Philippines and Thailand. Theoretical and empirical models of this study indicate that the US term premium had a significant role in the transmission of US monetary policy to Asia even previous to the 2008 financial crisis, and this link has gained strength as FED introduced its large-scale asset purchase programme in the post-crisis period. Furthermore, the results show that unconventional monetary policy of US spills over to Asia mainly through two channels: low domestic bond yields and rapid growth of domestic bank credit. Although it is seen that financial integration does not lessen the control of national monetary policy authorities over short-term policy rates, it poses a risk to control over long-term interest rates, which are the key determinants of real economic activity.

Sobrun and Turner (2015) emphasize that globalization makes financial conditions in developing countries closely linked to the 'world' long-term interest rate, which has been driven down particularly by monetary policies of major advanced economies. And, starting from this point of view, they investigate some new mechanisms for the transmission of global long-term interest rates to monetary policy and to domestic bank lending in the emerging markets. According to the results, although monetary policies in developing countries continue to be formed according to meet domestic objectives, the effects of domestic monetary policy rates on bond markets, on the exchange rate and on banks have to be considered by central banks of these countries. Since easy borrowing conditions in global markets have encouraged foreign investors to take risk, the size of the aggregate balance sheet of the domestic banking system in many emerging markets has also increased. Thereby, domestic bank credit expanded sharply in the emerging markets in the post-crisis period, and bank lending conditions have eased.

Kara (2016) investigates the macro-prudential policies applied in Turkey aftermath of the global crisis. These policies have been valuable in the process of dealing with macro financial risks, particularly the raised volatility in capital flows in the aftermath of the crisis. The unconventional monetary policy of US and easy global liquidity conditions were the main reasons of these capital flows. Besides, structural adjustments that occurred on fiscal, monetary and prudential dimensions in Turkey after the 2001 crisis have caused increases in capital inflows. With the effects of these financial improvements and increased global liquidity, Turkey, as an emerging economy, faced with rapid credit growth during the past decade, and private credit to GDP ratio rose sharply. Meanwhile, Turkish Lira appreciated rapidly in real terms, which in turn caused a sharp widening in the current account deficit. Because either short-term or portfolio flows was used to finance nearly all the current account deficit by the end of 2010, the Turkish economy became susceptible to sudden reversals in the global conditions. At this point, macro-prudential policies in Turkey have got involved and aimed to dampen the negative impacts of such sudden prospective reversals by improving external balances and reducing the sensitivity of the Turkish economy to capital flows. 


\section{S. Öner - C. İçellioğlu 12/1 (2020) 18-27}

Finally, the study of Rey (2018) conducts a VAR analysis applied to quarterly data of 53 countries over the 1990Q1-2012Q4 period, and examines effects of the global financial cycle on national monetary policies. Analysis results suggest that monetary policy in the US plays a crucial role in the global financial cycle by affecting leverage of global banks, capital flows and credit growth in the international financial system. By this channel, the "trilemma", which states that with free capital mobility, independent monetary policies are applicable if and only if exchange rates are floating, is transformed into a "dilemma" or an "irreconcilable duo", which states that independent monetary policies are applicable if and only if the capital account is conducted, directly or indirectly via macro-prudential policies. In other words, if capital is freely mobile, national monetary policies are constrained by the global financial cycle regardless of the exchange rate regime. To deal with the global financial cycle and the "dilemma" and thereby increase financial stability, Rey (2018) suggests four policy options: (i) imposing either cyclical or permanent capital controls to insulate the economy from the global financial cycle; (ii) internalization of the global spill-overs of the monetary policies of FED and other main central banks; (iii) controlling the transmission channel of the global financial cycle by taking cyclical precautions (macro-prudential policies) to limit excessive credit growth; (iv) controlling the transmission channel of the global financial cycle structurally by imposing stricter limits on leverage for all financial intermediaries.

\section{DATA AND METHODOLOGY}

In this study, the effects of FED policy rates on the total private non-financial credit to GDP ratios of emerging market economies are analysed by using panel data analysis. This analysis method makes possible to analyse both cross sectional and time series data. In other words, not only the variations in the characteristics of individuals, but also the changes in the variables over-time can be reviewed by panel data analysis.

\subsection{Definition of Variables and the Model}

The data set used in the analysis was acquired on 20 June 2019 from the Bank for International Settlements (https://www.bis.org/statistics/) and consists of 116 quarters between 1990 and 2018. The relationships between variables are examined for nine developing countries which are Austria, Brazil, China, Greece, India, Poland, Portugal, Russia and Turkey. Thus, the results are evaluated comparatively for the nine units and over the 29 year-time period. The model is stated in Equation 1 and the variables of the model are defined as follows.

Table 1. The Definition of Variables






\section{S. Öner - C. İçellioğlu 12/1 (2020) 18-27}

\subsection{Tests for the Presence of Unobservable Effects}

The problem of existence correlation between unobservable effects and explanatory variables can be controlled by using panel data (Hausman and Taylor, 1981). Individual effects and time period effects which are unobservable in the model, are respectively investigated by using Maximum Likelihood Method. The results of the test related to individual effects are given in Table 2. According to the results, the null hypothesis which suggests that "individual effects do not exist" has been rejected (prob $=0.0000$ ). The results of the test related to time effects are also given in Table 3. According to the results, the null hypothesis which suggests that "time period effects do not exist" could not be rejected (prob $=1.0000$ ). Therefore, it can be said that individual effects exist in the model although time period effects do not. In other words, the countries react differently to changes in explanatory variable but the countries' reaction don't change over time. Thus, the model is updated as follows because the intercept parameter varies according to the units.

Table 2. Testing for Individual Effects

\begin{tabular}{|c|c|c|c|c|}
\hline Random-effects Parameters & Estimate & Std. Err. & \multicolumn{2}{|c|}{ [95\% Conf. Interval] } \\
\hline \multicolumn{5}{|l|}{ _all: Identity } \\
\hline sd(R.id) & 43.30529 & 10.22976 & 27.25627 & 68.80429 \\
\hline sd(Residual) & 21.52829 & 0.4857789 & 20.59693 & 22.50177 \\
\hline LR test $:$ chibar2(01) $=1562.47$ & \multicolumn{4}{|c|}{ Prob $>=$ chibar $2=0.0000$} \\
\hline
\end{tabular}

Table 3. Testing for Time Period Effects

\begin{tabular}{lllll}
\hline Random-effects Parameters & Estimate & Std. Err. & \multicolumn{2}{l}{$[95 \%$ Conf. Interval $]$} \\
\hline $\begin{array}{l}\text { all: Identity } \\
\text { sd(R.t) }\end{array}$ & 372.5578 & 431.9042 & 38.4061 & 3613.991 \\
sd(Residual) & 46.77883 & 1.050665 & 44.76423 & 48.88409 \\
LR test: chibar2(01) $=0.00$ & \multicolumn{3}{c}{ Prob $>=$ chibar2 $=1.0000$} \\
\hline
\end{tabular}

\subsection{Existing Tests of Homogeneity and the Final Model}

The homogeneity of both the slope parameter and the intercept parameter should be tested. Homogeneity is tested through the standard F Test and Swamy's test. In the F Test, the null hypothesis suggests that the parameters are homogeneous $\left(\beta_{i}=\beta\right.$ for all $\left.i\right)$. The F Test statistic can be calculated using the following Equation 3. If the value calculated for the $F$ Test is greater than the table value $[\mathrm{F}$ table $=\alpha ; \mathrm{K}(\mathrm{N}-1) ; \mathrm{N}(\mathrm{T}-\mathrm{K})]$, the null hypothesis is rejected (Tatoğlu, 2018).

$F=\frac{(R R S S-U R S S) / K(N-1)}{U R S S / N(T-K)}$

The residual sum of squares from unrestricted regression (URSS) is calculated as 353,093 . However, the residual sum of squares from restricted regression (RRSS) is obtained as 2,348,971. The F statistic of the twovariable model, where the number of cross sectional units $(\mathrm{N})$ is 9 and the number of time series $(\mathrm{T})$ is 116 , is calculated as 362 [F calculation $=362]$. $\mathrm{F}$ table value is also 1.70 [F table $=0.05 ; 16 ; 1026]$. Since "F calculation > F table", the null hypothesis, which states that the parameters are homogeneous by country, is rejected. 


\section{S. Öner - C. İçellioğlu 12/1 (2020) 18-27}

Swamy's test is also applied for parameter constancy. This test is based on the dispersion of individual slope estimates obtained from a suitable pooled estimator (Pesaran and Yamagata, 2007). As a result of the test, chi2 $(16)=7733.95$ and prob $>$ chi $2=0.0000$ values have been obtained. These results show that slope parameters are different from each other and the panel has a heterogeneous feature. A heterogeneous panel can be expressed as follows (Equation 4).

$y_{i t}=\beta_{0 i}+\beta_{1 i} X_{i t}+u_{i t}$

\subsection{Tests For Cross-Sectional Dependence}

In heterogeneous panels, an appropriate estimation method is determined based on the existence of error cross-section independence. If there is a correlation among the series in the panel, the residues obtained from the models are related to each other. Even if the units seem different from each other, they may have been influenced by similar factors over the same time period. Therefore, the error terms of the models of these units may be related.

Table 4. Error cross-section independence

\begin{tabular}{lll}
$\left(\mathrm{H}_{0}: \operatorname{Cov}(\right.$ uit, ujt $)=0$ for all $\mathrm{t}$ and $\mathrm{i} !=\mathrm{j}$ & & \\
Test & Statistics & p-value \\
\hline LM & 1702 & 0.0000 \\
LM adjusted (two sided test) & 1069 & 0.0000 \\
LM CD (two sided test) & 38.56 & 0.0000 \\
\hline
\end{tabular}

Table 4 shows the results of the error cross-section independence test. According to the Lagrange-Multiplier (LM) test statistics, the null hypothesis which suggests that "there is no cross-sectional dependence" is rejected. In addition, Breusch-Pagan Test of independence also confirms this result [chi2 (36) = 1701.881, $\operatorname{Pr}=0.0000$ ]. The correlation matrix of residuals and the relationships between variables are presented in Table 5 . When the correlation matrix of the residuals is examined, a high correlation is observed between some countries. As the values converge to 1 , the relationship between countries becomes stronger. It can be seen that the credit markets of Brazil, China, Poland, and Russia are strongly related to Turkey's credit market.

Table 5. Correlation Matrix of Residuals

\begin{tabular}{|c|c|c|c|c|c|c|c|c|c|c|}
\hline $\begin{array}{l}\text { Credit } \\
\text { GDP }\end{array}$ & to & Austria & Brazil & China & Greece & India & Poland & Portugal & Russia & Turkey \\
\hline Austria & & 1 & & & & & & & & \\
\hline Brazil & & 0.1760 & 1 & & & & & & & \\
\hline China & & 0.4329 & 0.8322 & 1 & & & & & & \\
\hline Greece & & 0.8455 & 0.5396 & 0.6178 & 1 & & & & & \\
\hline India & & 0.8421 & 0.4798 & 0.5594 & 0.9814 & 1 & & & & \\
\hline Poland & & 0.7118 & 0.7626 & 0.8579 & 0.8769 & 0.8387 & 1 & & & \\
\hline Portugal & & 0.8729 & -0.065 & 0.1281 & 0.7463 & 0.7666 & 0.4579 & 1 & & \\
\hline Russia & & 0.6672 & 0.7170 & 0.7919 & 0.8646 & 0.8583 & 0.9296 & 0.4556 & 1 & \\
\hline Turkey & & 0.4361 & 0.8979 & 0.8902 & 0.7412 & 0.6862 & 0.9142 & 0.1503 & 0.8609 & 1 \\
\hline
\end{tabular}

\subsection{The Model Estimation with Seemingly Unrelated Regressions}

Arnold Zellner (1962) developed the SUR for the models which have cross-section dependence, and Baltagi and Raj (1992: 91) searched theoretical developments in the econometrics of panel data and the SUR model. They pointed out that Avery (1977), who suggested estimates of the variance-components that are predicated 


\section{S. Öner - C. İçellioğlu 12/1 (2020) 18-27}

on Ordinary Least Squares (OLS) residuals, improved the SUR model with error component disturbances. Baltagi (1980) derived this variance-covariance matrix and recommended a substitute estimation. In this model, Generalised Least Squares (GLS) on the whole system is equal to GLS on each equation separately. Verbon (1980) improved the SUR model with heteroscedastic specification. For the case where the time series dimension is sufficiently large (around 80-100) and the cross-section dimension is reasonably small (around 510), the estimates of SUR are asymptotically efficient (Pesaran and Yamagata, 2007). Thereby, since the number of cross-sectional units in our panel data analysis is 9 and the time dimension is large, it is appropriate to apply the SUR model. Because the individuals in the panel are heterogeneous, a separate model is estimated for each individual and so the results could be interpreted in units.

Table 6. The General Results of Seemingly Unrelated Regression Model

\begin{tabular}{llll}
\hline Equation & R-sq & Chi2 & P \\
\hline Austria & 0.6012 & 138.67 & 0.0000 \\
Brazil & 0.4978 & 91.19 & 0.0000 \\
China & 0.5000 & 92.01 & 0.0000 \\
Greece & 0.6470 & 168.66 & 0.0000 \\
India & 0.5682 & 121.04 & 0.0000 \\
Poland & 0.6850 & 200.08 & 0.0000 \\
Portugal & 0.6327 & 158.49 & 0.0000 \\
Russia & 0.5534 & 113.98 & 0.0000 \\
Turkey & 0.4030 & 62.11 & 0.0000 \\
\hline
\end{tabular}

By means of the SUR model, 9 model estimation results have been derived for the 9 countries in the panel. According to the results, while FED policy rates increase, total private non-financial credit to GDP ratios of emerging market economies decrease. Therefore, a negative relationship has been found between FED policy rates and the credit growth of emerging market economies. In reference to parameter estimates, changes in FED policy rates principally affect credit markets of Portugal, Greece and China.

R-squared value shows the percentage of the total change in the dependent variable that can be explained by the independent variable. Analysis results indicate that the models which have the highest explanatory power are the models of European countries and these countries are respectively Poland, Greece, Portugal and Austria. Russia, India, China, Brazil and lastly Turkey follows the European countries in the manner of explanatory power of independent variable. The effect of FED policy rates on the private non-financial credit to GDP ratio appears to be higher in European countries. This finding is consistent with the findings of Lane and McQuade (2013) which indicate that international capital flows have strong effects on the national credit growth rates for a sample of European countries over the 1993-2008 period. On the other hand, the R-squared value of the model of Turkey is $40 \%$. This means that only 40 percent of the changes in the private nonfinancial credit to GDP ratio of Turkey can be explained with FED policy rates. 
S. Öner - C. İçellioğlu 12/1 (2020) 18-27

Table 7. The Parameter Estimates of Seemingly Unrelated Regression Model

\begin{tabular}{lll}
\hline $\begin{array}{l}\text { Credit/GDP } \\
\text { (Dependent Variable) }\end{array}$ & $\begin{array}{l}\text { Policy rate } \\
\text { (Independent Variable) }\end{array}$ & Cons. \\
\hline Austria & -4.1379 & 143.6934 \\
& $(0.0000)$ & $(0.0000)$ \\
Brazil & -3.1293 & 63.2264 \\
& $(0.0000)$ & $(0.0000)$ \\
China & -12.2648 & 167.9505 \\
& $(0.0000)$ & $(0.0000)$ \\
Greece & -12.6812 & 121.2902 \\
& $(0.0000)$ & $(0.0000)$ \\
India & -4.2822 & 57.0986 \\
& $(0.0000)$ & $(0.0000)$ \\
Poland & -7.4700 & 75.8565 \\
& $(0.0000)$ & $(0.0000)$ \\
Portugal & -13.7314 & 209.3671 \\
& $(0.0000)$ & $(0.0000)$ \\
Russia & -5.9330 & 57.0195 \\
& $(0.0000)$ & $(0.0000)$ \\
Turkey & -6.6465 & 62.2267 \\
& $(0.0000)$ & $(0.0000)$ \\
\hline
\end{tabular}

\section{CONCLUSION}

By means of the monetary transmission mechanisms, monetary policy implications can dominate real economy. Monetary policy rates are expected to have a strong impact on the credit, investment, and national product levels of economies by means of the credit channel of monetary transmission. On the other hand, consumption, production and investment decisions of households, firms and credit institutions are not only determined by interest rates. Therefore, as a result of the accelerating globalization process, the credit transaction volume of economies is under the influence of economic, political, legal, and psychological factors in both domestic and foreign markets. For this reason, policymakers in each country should consider economic developments in other countries, especially in the advanced economies, when making their decisions. As experienced once again after the 2008 global crisis, US monetary policy implementations constitute the most important part of these developments.

Literature survey also confirms this finding and reveals that monetary policy in the US plays a crucial role in the global financial cycle by affecting leverage of global banks, capital flows and credit growth in the international financial system. From this point of view, the effect of US monetary policy on the credit growth of emerging market economies is examined for the 1990-2018 period in this study. As expected, the relationship between FED policy rates and the private non-financial credit to GDP ratios of selected emerging market economies has been found to be statistically significant. However, the strength of this relationship is not the same for all countries. According to the results obtained from the SUR estimation method, which is suitable for heterogeneous panel data, the highest impacts of FED policy rates on the private non-financial credit to GDP ratios of emerging market economies are observed in the European countries. Russia, India, China, Brazil and lastly Turkey respectively follows the European countries in the manner of this relationship. Therefore, the effect of FED policy rates on the private non-financial credit to GDP ratio appears to be higher particularly in European countries. On the other hand, the influence of economic, political, legal, and psychological factors other than FED policy rates seem to have strong effects particularly on the credit markets of Russia, India, China, Brazil, and Turkey. 


\section{S. Öner - C. İçellioğlu 12/1 (2020) 18-27 \\ REFERENCES}

Adrian, T. and Shin, H.Y. (2009). Prices and Quantities in the Monetary Policy Transmission Mechanism, International Journal of Central Banking, 5 (4), 131-142.

Avery, R. B. (1977). Error Components and Seemingly Unrelated Regressions, Econometrica, 45(1), 199-208.

Baltagi, B.H. (1980). On Seemingly Unrelated Regressions with Error Components, Econometrica, 48(6), 15471551.

Baltagi, B.H. and Raj, B. (1992). A Survey of Recent Theoretical Developments in the Econometrics of Panel Data, Empirical Economics, 17, 85-109.

Bank for International Settlements, Statistics, [online] https://www.bis.org/ (Accessed on June 2019).

Borio, C. and Zhu, H. (2008). Capital regulation, Risk-Taking and Monetary Policy: A Missing Link in the Transmission Mechanism?, BIS Working Papers, No.268.

Bowman, D., Londono, J.M. and Sapriza, H. (2014), U.S. Unconventional Monetary Policy and Transmission to Emerging Market Economies, Board of Governors of the Federal Reserve System, International Finance Discussion Papers, No: 1109.

Bruno, V. and Shin, H.S. (2013). Capital Flows and the Risk-Taking Channel of Monetary Policy, NBER Working Paper Series, No: 18942.

Fendoğlu, S., Kılınç, M. and Yörükoğlu, M. (2014). Cross-Border Portfolio Flows and the Role of Macroprudential Policies: Experiences from Turkey, BIS Papers, No: 78.

Gourinchas, P.O. and Obstfeld, M. (2011). Stories of the Twentieth Century for the Twenty-First, NBER Working Paper Series, No: 17252.

Hausman, J.A. and Taylor, W.E. (1981). Panel Data and Unobservable Effects, Econometrica, 49(6), 1377-1398.

Kara, H. (2016). Turkey's Experience with Macroprudential Policy, BIS Papers, No: 86, 123-139.

Lane, P.R. and McQuade, P. (2013). Domestic Credit Growth and International Capital Flows, European Central Bank Working Paper Series, No: 1566.

Miyajima, K., Mohanty, M.S. and Yetman, J. (2014). Spillovers of US Unconventional Monetary Policy to Asia: The Role of Long-Term Interest Rates, BIS Working Papers, No: 478.

Pesaran, M. H. and Yamagata, T. (2007). Testing Slope Homogeneity in Large Panels, Journal of Econometrics, $142(1), 50-93$.

Rey, H. (2018). Dilemma Not Trilemma: The Global Financial Cycle and Monetary Policy Independence, NBER Working Paper Series, No: 21162.

Sobrun, J. and Turner, P. (2015). Bond Markets and Monetary Policy Dilemmas for the Emerging Markets, BIS Working Papers, No.508.

Takáts, E. and Vela, A. (2014). International Monetary Policy Transmission, BIS Papers, No: 78.

Tatoğlu, F.Y. (2018). Illeri Panel Veri Analizi, Istanbul, Beta Basım A.Ş.

The Central Bank of the Republic of Turkey (2014) “Bulletin”, March 2014 (33).

Zellner, A. (1962). An Efficient Method of Estimating Seemingly Unrelated Regressions and Tests for Aggregation Bias, Journal of the American Statistical Association, 57 (298), 348-368. 